${ }^{\circledR}$ Entomologica Fennica. 5 December 1995

\title{
Threatened insects of Ruissalo
}

\author{
Kari Karhu, Pertti Rassi \& Ilpo Rutanen
}

Karhu, K., Rassi, P. \& Rutanen, I. 1995: Threatened insects of Ruissalo. Entomol. Fennica 6:123-125.

The threatened species of the insect orders Heteroptera, Lepidoptera and Coleoptera found in Ruissalo, an island with widest oak forests of Finland, are listed. Of the 154 species of threatened Lepidoptera in Finland 12\% (19 species) and of the 332 species of threatened Coleoptera $16 \%$ (53) are found in Ruissalo. A considerable part of the threatened species of both Lepidoptera and Coleoptera are dependent on oak. The most important areas of the oak forests are already under protection and the other parts of them belong to the national conservation program of herb-grass forests. A forestry plan prepared by the City of Turku considers the nature values of the island of Ruissalo.

Kari Karhu, Environmental Protection Office, City of Turku, Linnankatu 61, FIN-20100 Turku, Finland

Pertti Rassi, Ministry of the Environment, P.O. Box 399, FIN-00121 Helsinki, Finland

Ilpo Rutanen, Finnish Environment Agency, P.O. Box 250, FIN-00101 Helsinki, Finland

\section{Introduction}

Ruissalo is a seven kilometres long island off Turku, on the southwestern coast of Finland. The main part of the island is preserved as recreation area. The island is characterized by extensive herb-grass forests dominated by oak, and even on pine-dominated heaths oak is growing as mixed tree. Also meadows and fields between deciduous forests belong to the landscape of Ruissalo. The total area of the oak-dominated woodland is 170 hectares, representing approximately the half of all oak-forests of Finland.

Numerous threatened species of organisms, especially beetles and fungi dependent on living or dead oaks, are found on the island. Of the threatened species of beetles in Finland 53 have been found in Ruissalo. At least 22 of them, 14 depending on oak, may still be found on the island.

Another important group of insects is butterflies and moths. In Ruissalo 19 threatened species have been found, of which only four are found furthermore. Of these three are feeding on oak or the lichens growing on oak.

The most important oak forest areas are protected and the other areas belong to the national conservation program of herb-grass forests. The land is owned by the city of Turku, which is going to apply for protection according to the nature conservation law for the most important objects. A forestry plan, which is considering nature values and favouring oaks, is prepared by 
the city of Turku for the forests of Ruissalo. According to this plan dead or dying trees are not cut down even on the not-protected forest areas, and clearing of the forests has been decreased. Additionally, removing of spruces from the herbgrass forests and pasturing of the meadows has been started.

\section{List of threatened species}

In the following list of the threatened species of insects, belonging to the well known orders Heteroptera, Lepidoptera and Coleoptera, found in Ruissalo, the classification follows the Report on the Monitoring of Threatened Animals and Plants in Finland (Rassi \& al. 1992). Of each species the latest year of observation is given. The names of the species found during the last ten years are marked with plus (+); species known only from Ruissalo are marked with an asterisk (*) and species dependent on oak are marked with a dot $\left({ }^{\circ}\right)$. The knowledge about other insect orders (e.g. Diptera and Hymenoptera) is so insufficient, that these orders are not treated.

\section{Heteroptera}

In need of monitoring

- rare:

Tritomegas bicolor (Linnaeus)

Temnostethus pusillus (Linnaeus)'

1956

\section{Lepidoptera}

\section{Disappeared}

Acronicta cuspis (Hübner) ${ }^{2}$

\section{Endangered}

Moma alpium (Osbeck) ${ }^{2,4}$

\section{Vulnerable}

Parnassius apollo (Linnaeus)

Alcis jubatus (Thunberg)

\section{In need of monitoring}

- declining:

Acrobasis sodalella (Hübner) ${ }^{\circ}$

Maniola jurtina (Linnaeus)

Issoria lathonia (Linnaeus)

Herminia lunalis (Scopoli) ${ }^{2}$

Melanchra persicariae (Linnaeus)

Euxoa recussa (Hübner)

undated $^{3}$

Agrotis segetum (Denis\& Schiffenmüller) ${ }^{2}$

$1944^{3}$

1950's

1938

$1983^{3}$

$1967^{3}$

1956

1922
- rare:

Ectoedemia atrifrontella (Stainton) $+* 0$

Acrocercops brongniardellus (Fabricius) ${ }^{\circ}$

Hesperia comma (Linnaeus) ${ }^{2}$

1970's

$1983^{3}$

1952

1994

Eupithecia dodoneata (Guenée)+

Nycteola revayana (Scopoli) $+{ }^{\circ}$

Orthosia munda (Hübner)+* I

1994

- poorly known:

Microthrix similella (Zincken) $^{\circ}$

1950 ’s

\section{Coleoptera}

\section{Disappeared}

Calosoma inquisitor (Linnaeus)*o

1945

Lebia cyanocephala (Linnaeus)

Trox sabulosus (Linnaeus) ${ }^{\circ}$

Meloe brevicollis (Panzer)

undated

ca 1880

1916

\section{Endangered}

Dendroxena quadrimaculata (Scopoli)*

Aphodius subterraneus (Linnaeus)

1962

Osmoderma eremita (Scopoli)+*o

Cenuchus chrysomelinus (Hochenwarth) ${ }^{\prime}$

Athous mutilatus (Rosenhauer)+

Lyctus linearis (Goetze) ${ }^{\circ}$

Strangalia attenuata (Linnaeus)

ca 1950

1993

undated

1993

1946

1950

\section{Vulnerable}

Hypnogyra glabra (Nordmann) $+{ }^{\circ}$

1993

Paromalus flavicornis (Herbst)

1948

1961

Oplocephala haemorrhoidalis (Fabricius) ca 1830

Anoplodera sexguttata (Fabricius) $+{ }^{\circ}$

1988

Phymatodes testaceus (Linnaeus)+

1985

Phymatodes alni (Linnaeus) ${ }^{\circ}$

1944

Plagionotus arcuatus (Linnaeus)

1918

Mesosa myops (Dalman) $+* 0$

1991

Macroplea pubipennis (Reuter)

Orsodacne cerasi (Linnaeus)+*

ca 1930

1992

\section{In need of monitoring}

- declining:

Panagaeus cruxmajor (Linnaeus)

1947

Chlaenius nigricornis (Fabricius)

1941

Philonthus longicornis (Stephens) ca 1940

Dinothenarus pubescens (Degeer)

Liocola marmorata (Fabricius) $+{ }^{\circ}$

ca 1930

1993

1930's Platycerus caraboides (Linnaeus) 
Selatosomus nigricornis (Panzer)+ Ampedus praeustus (Fabricius) $+^{\circ}$ Malachius aeneus (Linnaeus) Silvanus unidentatus (Olivier)

Halyzia sedecimguttata (Linnaeus)

Mycetophagus quadripustulatus

(Linnaeus)

Melandrya dubia (Schaller)

Longitarsus parvulus (Paykull)

Ceutorhynchus pleurostigma (Marsham)

- rare:

Quedius microps (Gravenhorst)

Plectophloeus nitidus (Fairmaire) $+{ }^{\circ}$

Plegaderus caesus (Herbst) $+^{\circ}$

Ampedus nigroflavus (Goeze) $+^{\circ}$

Epuraea guttata (Olivier)+ ${ }^{\circ}$

Cryptarcha strigata (Fabricius) $+{ }^{\circ}$

Triplax rufipes (Fabricius) $+{ }^{\circ}$

Hyperaspis inexpectata (Günther)+

Pentaphyllus testaceus (Hellwig)+*o

Prionychus ater (Fabricius)+

Mycetochara humeralis (Fabricius)

Scraptia fuscula (Müller) $+{ }^{\circ}$

Clytus arietis (Linnaeus)

Oplosia fennica (Paykull)+
1984 - poorly known:

1993 Aphodius serotinus (Panzer) undated

1916 Sulcacis fronticornis (Panzer) 1919

1919 Donacia marginata (Hoppe)+ 1993

1947

ca 1830

ca 1830

1943

1910

ca 1940

1993

1993

1993

1993

1993

1988

1984

1993

1993

1961

1989

ca 1900

1989

1 classification of endangerment unofficial: species new to Finland or the state of the occurrence of the species is changed

${ }^{2}$ the regional class of endangerment mentioned in Committee's report is used

${ }^{3}$ the find location is given with coordinates only, the species is most probably collected in Ruissalo

${ }^{4}$ the species has probably never had breeding population in Ruissalo

\section{Reference}

Rassi, P., Kaipiainen, H., Mannerkoski, I. \& Stăhls, G. 1992: Uhanalaisten eläinten ja kasvien seurantatoimikunnan mietintö.(Report on the monitoring of threatened animals and plants in Finland). - Report No. 30/1991, (in Finnish with English summary). - Ministry of the Environment, Helsinki. 328 pp. 